\title{
Distribution Of Different Religion Legacy According To Islamic Instruction Law (Case Study Of The Supreme Court Decision Number 368 K/Ag/1995)
}

\author{
Edy Sanjaya $^{1 *}$, Indira Hastuti ${ }^{2}$, Budi Prasetyo ${ }^{3}$ \\ 1,2,3 Faculty of Law, University of 17 August 1945 Semarang, Indonesia \\ * Corresponding author: \\ Email: edysanjaya7676@gmail.com
}

\begin{abstract}
.
The decision of the Supreme Court regarding the granting of wills to non-Muslim heirs is a breakthrough in relation to the inheritance of different religions. It is the consensus of scholars that religious differences (Muslims and non-Muslims) are one of the barrier factors for inheriting. With regard to religious differences, the mandatory will given by the Supreme Court is for non-Muslim siblings. The compulsory intention in $\mathrm{KH} 1$ is analogous to adopted children and adoptive parents. Religious differences are still barriers to inheriting each other by seeking a positive step by not limiting the understanding of inheritance law so far. This research method uses a normative juridical approach by reviewing various literature on granting wills to non-Muslim heirs. Data was collected through a literature study with relevant secondary legal materials sourced from statutory regulations, literature, both books, journal articles. Who are Muslim. It is the same with a Muslim who cannot inherit from a non-Muslim.
\end{abstract}

Keywords: Inheritance, different religions, heirs, Islamic law, supreme court decision

\section{INTRODUCTION}

According to Abdul Ghofur Anshori [1] Inheritance is a science related to property, if the distribution is not transparent and based on clear legal force [2]. It is feared that in the future it will cause a dispute between the heirs. Therefore, Islamic inheritance is seen as very urgent in Islam. As the name implies, Islam is a religion that wants peace in all fields, including having a preventive commitment from all things that can damage the unity and integrity of the ummah.

For the Indonesian people who adhere to various religions and beliefs, they have a form of kinship with different hereditary systems. These different hereditary systems affect the inheritance system in that society. Among native Indonesians there is not a single familial trait, but in various regions there are various familial traits that can be included in the league of groups, namely:

1. the nature of fatherhood (patriarchaat),

2. maternal nature (matriarchaat), and

3. fatherly nature (parental) 
Thus, if it is considered as stated by Edy Sanjaya [3], that the inheritance law that applies in Indonesia is pluralistic, meaning that there are various inheritance laws, including:

1. Islamic Inheritance Law

2. Inheritance Law regulated according to the Civil Code

3. Customary Inheritance Law

The validity of the 3 types of inheritance law is due to the absence of a nationally valid inheritance law unification.

Recently, there has been a dynamic and legal progress related to the issue of inheritance of different religions. This development can be seen from the fact that the Supreme Court of the Republic of Indonesia has made a breakthrough regarding the inheritance of different religions. The breakthrough can be clearly seen from; its decisions that provide gaps and opportunities for non-Muslim parties to be able to receive a share of the property of Muslim heirs. This opportunity is not provided in the form of pure inheritance practice, but is made by using the concept or rules of the Mandatory Will [4].

The application of the legal institution of mandatory wills in cases of disputes between adopted children and heirs of different religions in Indonesia is a new legal development [5]. Specifically regarding heirs of different religions who are given inheritance through a mandatory will must go through various in-depth legal considerations, so that between cases one does not always have the same applied law [6]. The concept of obligatory will at first was only intended for heirs or relatives who did not get a share of the inheritance of the deceased, because of a syara' obstacle. For example, making a will to a non-Muslim mother or father. This concept was born as a policy of the ruler (ulil amri) towards people who do not leave a will, while he has a lot of inheritance. It means, The policy in the mandatory will is more qadhaiyah in nature, in the sense that the obligation to issue a portion of the inheritance as a will is no longer based on the presence or absence of a person leaving a will during his lifetime, but on the applicable laws or regulations. So that even if a person does not have a will during his life, it is automatically considered a will[7].

From the description above, the meaning of mandatory will as stated by Mardani[8] is an action taken by a ruler or judge as a state apparatus to force, or give a mandatory decision on a will for a deceased person, which is given to a certain person under certain circumstances.

a. The disappearance of the element of effort of the testator and the emergence of an element of obligation through the regulations of the testator.

b. There is a resemblance to the provisions on the distribution of inheritance in terms of acceptance of men 2 times the share of women.

In the Compilation of Islamic Law in Indonesia, the term will must be mentioned in Article 209 Paragraph 1 and Paragraph 2, as follows:[9]. 
1. the inheritance of the adopted child is divided based on Article 176 to Article 193 of the KHI, while the adoptive parents who do not receive a will are given a mandatory will of a maximum of $1 / 3$ and the inheritance of their adopted child;

2. To an adopted child who does not receive a will, he is given a mandatory will of $1 / 3$ and the inheritance of his adoptive parents.

Based on the contents of Article 209 KHI Paragraphs I and 2 above, it can be understood that the mandatory testament referred to by KHI is a will that is required under the provisions of the legislation intended for adopted children or vice versa for adoptive parents who were not given a will before by the adoptive parents or adopted children, with a maximum amount of $1 / 3$ and inheritance.

Provisions that are almost similar to mandatory wills have been regulated in Article 185 of the Compilation of Islamic Law, which reads:

Paragraph (1): An heir who dies before the heir, then his position can be replaced by his child, except those mentioned in Article 173

Paragraph (2): "The share of the successor heirs may not exceed the share of the heirs who are equal to the heirs being replaced".

From the provisions of the article it can be stated that an heir who has died before the heir, if the heir has children, then his position is replaced by his children, and the share received by his children must not exceed the share of equal heirs. with which it is replaced.

Furthermore, with the Supreme Court's decision regarding the granting of wills to non-Muslim heirs, this is a new breakthrough in relation to inheritance of different religions. The breakthrough can be seen from; decisions that provide opportunities for non-Muslims to receive a share of the property of Muslim heirs.

\section{METHODS}

The legal research used is normative legal research with a statutory, concept, and case approach. The collecting of legal materials is done through literature studies related to the distribution of wills for non-Muslim heirs. The legal material analysis technique used is juridical analysis.

\section{RESULT AND DISCUSSION}

\section{A. Islamic inheritance for heirs of different religions.}

1. Sources of Islamic Inheritance Law

Islamic Inheritance Law as part of Islamic Shari'ah and more specifically as part of the mu'amalah aspect of sub-civil law. What was said by Endang Syaifuddin as quoted by Abdul Ghofur Anshori [10]. inseparable from other aspects of Islamic 
teachings. Therefore, the compilation of Islamic inheritance law principles is based on the same source as other aspects of Islamic teachings. The sources of Islamic law are the Koran, the Sunnah of the Prophet, and Ijtihad. These three sources are also the basis of Islamic inheritance law. The use of these three sources is based on the verses of the Koran itself and the Hadith of the Prophet. One of the verses that alludes to this is Surah an-Nisa" verse 59:

Meaning: "O you who believe, obey Allah and obey His (Rasul) and Uli al-Amri among you. Then if you disagree about something, then return it to Allah (al-Quran) and the Messenger (Sunnah) (Surat an-Nisa': 59).

This verse gives an understanding that believers are required to obey Allah, the Messenger, and Uli al-Amri. This can be given the understanding that a believer in solving various problems must base himself on these three sources. Therefore, the notion of obeying Allah is interpreted by obeying what is in the Koran, while obeying the Apostle is defined as obeying the Sunnah of the Prophet, and obedience to Uli alAmri is interpreted by obeying the results of the Ijtihad of the Mnjtahid scholars. .

Heirs are people who at the time of death of the heirs have blood relations or marital relations with the heirs, are Muslim and are not hindered by law from becoming heirs[10]

The difference in religion in inheritance law is when the heirs and muwarrits are of different religions. So, heirs of different religions are heirs of religions other than and from Islam.

As for the causes of inheritance according to Islamic inheritance law, namely the existence of kinship relations, marital relations and Islamic teachings.

On the other hand, the things that cause the heirs to lose their right to inherit or are prevented from inheriting include [11]:

a. Slavery

From the very beginning, Islam wanted slavery to be abolished, but in reality slavery has spread everywhere and is difficult to abolish. Therefore, slavery has a place in the discussion of Islamic law. In the Qur'an it has been described that a slave is not capable of managing property rights in any way. This is in accordance with the Word of Allah Surah An-Nahl verse 75 which means that Allah has made the parable of a slave who cannot do anything.

The status of a slave cannot be an heir, because he is considered incompetent to take care of property and has cut off family relations with his relatives. There are even those who view the slave's status as the property of his master, he cannot inherit his inheritance, because he himself and all the property that is in him belongs to the master. He has no treasure

b. Murder

Islamic jurists agree that the act of murder committed by the heir against his heir, in principle becomes a barrier for him to inherit the inheritance of the heir who was killed. Based on the hadith of the Prophet. SAW means whoever 
kills a victim, he cannot inherit it, even though the victim has no heir other than himself and if the victim is the father or son, then there is no right to inherit for the killer. (HR. Imam Ahmad)

Given the many forms of murder, the jurists differ on which type of killing is a barrier to inheritance. The jurists of the Shafiya school by adhering to the generality of the hadith above argue that all forms of murder committed by the heir to the heir are a barrier for him to inherit.

According to the jurists of the Hanafi school, there are four types of killings that become a barrier to inheriting, namely as follows:

1) Intentional homicide, namely premeditated murder.

2) Murder is similar to intentional (syibhul 'amdi) for example, intentionally doing torture with a punch without the intention to kill him, but it turns out that the one who was hit dies.

3) Murder by mistake, for example, a hunter who shoots dead what he thought was a monkey, after being approached it turned out to be a human. Or someone who is practicing shooting right at a tree target, but misses his father who is nearby.

4) Murder is considered a mistake, for example a person carrying a heavy object accidentally drops his brother to death.

According to the Malikiyah jurists, there are three types of killings that hinder inheritance, namely as follows. '

1) Deliberate murder

2) Killer looks like on purpose

3) Indirect intentional killing by mistake.

According to the Hanabilah school of jurisprudence, the types of murder that hinder the right to inherit are as follows.

1) Intentional murder.

2) Murder is like intentional.

3) Murder by mistake.

4) Murder is considered a mistake.

5) Indirect murder.

6) Murder committed by incompetent people (children or crazy people)

c. Different Religions

Different religions are religious differences that become beliefs between the person who inherits and the person who inherits. The legal basis for different religions as Mawani 'ul Irsi is the Hadith of the Prophet Muhammad SAW which means that Muslims cannot inherit the property of infidels and unbelievers cannot inherit the property of Muslims.

Islamic jurists (jumhur ulama) agree that non-Muslims cannot inherit the property of Muslims because the status of non-Muslims is lower. This is 
explained by Allah SWT. In Surah An-Nisaa verse 141 it means And Allah will never give way to the disbelievers to destroy those who believe.

If an heir of a different religion some time after the death of the testator and then converts to Islam, while the inheritance has not been distributed, then an heir who has just converted to Islam is still prevented from inheriting, because the emergence of the right to inherit is since the death of the person who inherits, not when the distribution of inheritance begins. Even though at the time of the death of the heir, he was still in a non-Islamic state (infidel). So, they are in a state of different religion.

If the conditions for obtaining inheritance rights only begin at the time of the distribution of inheritance, of course there are legal differences regarding prioritizing and ending the distribution of inheritance, and of course such rights can be abused by heirs who convert to Islam only to obtain inheritance and then fall back after achieved meaning.

Likewise, apostates (people who leave/leave from Islam) have the same position, namely not inheriting the inheritance of their family. The person who apostates means that he has committed the greatest crime that has decided the shilah of sharia. Therefore, the jurists have agreed that an apostate is not entitled to inherit property from his relatives [12]. As Allah says in Surah AlBaqarah verse 217 which means "Whoever apostates among you from his religion, then he dies in disbelief, then they are tuìh whose deeds are in vain in this world and in the hereafter and they are the inhabitants of hell, they will abide in it.

The condition for the heirs to be said to be heirs is Muslim, so heirs who are not Muslim are not entitled to only inheritance due to different religions or not being Muslim. However, heirs of different religions are entitled to inherit property through Wasíat or Wasíat obligatory. A will is a tasharruf of the inheritance that will be carried out after the death of the person who has washiyyat.

Furthermore, in matters relating to the giving of mandatory wills to heirs of different religions. Scholars have different opinions regarding the provisions of the mandatory will. The difference of opinion among the scholars regarding the existence of a mandatory will is found in the application of nasakh (nasikhmansukh) to Surah Al-Baqarah verse 180. Scholars who do not apply a mandatory will for their parents and close relatives are of the opinion that verse 180 of letter A1-Baqarah has been written down (deleted or omitted by law) by the verses of Inheritance, hadith and ijma. Meanwhile, scholars who enforce mandatory wills for their parents and close relatives are of the opinion that verse 180 of Surah A1-Baqarah is not narrated by the Mawaris verses in A1-Qur'an and A1-Hadith, another opinion is verse 180 of Surah Al-Baqarah in takhsis by inheritance verses, in the sense that parents and relatives who do not receive inheritance are given a will [13]. 


\section{B. Decision of the Supreme Court No. 368 K/AG/1995 concerning the granting of a mandatory will to heirs of different religions.}

It is the consensus of scholars that religious differences (Muslims and nonMuslims) are one of the hindering factors in being able to inherit. With regard to religious differences, what was agreed upon by these scholars was that non-Muslim heirs, either because from the start they were not Muslim (kafir) or out of Islam (apostate), could not inherit Muslim heirs.

The mandatory will given by the Supreme Court is for non-Muslim siblings. In fact, the mandatory will in $\mathrm{KH} 1$ is analogous to adopted children and adoptive parents, while religious differences are still one of the barriers to inheriting each other. by seeking a positive step by not limiting the understanding of inheritance law so far In the law of inheritance it has been explained that a person who comes out of the Islamic religion is not entitled to inherit from his Muslim relative. It is the same with a Muslim who cannot inherit and a non-Muslim [13].

According to Azhar Basyir, the difference in religion between heirs and heirs is a barrier to inheritance, but if the husband and wife have different religions, for example, the husband is Muslim and the wife is Christian, then the husband or wife after one of them dies can enjoy the property. inheritance, and this can be done through a will.[14]

In reality, in the Religious Courts environment, non-Muslim heirs get a share of the inheritance of Muslim heirs through the mandatory wasíat since the decision of cassation Number $368 \mathrm{~K} / \mathrm{Ag} / 1995 \mathrm{In}$ this decision, a non-Muslim daughter's biological daughter gets a share of the inheritance from her Muslim parents through mandatory will with the same share as Muslim heirs. This decision has been followed by a decision on cassation Number $51 \mathrm{~K} / \mathrm{Ag} / 1999$ dated September 29, 1999, Number 721 K/AG/2017 dated November 19, 2015, and a decision on cassation Number 218 $\mathrm{K} / \mathrm{AG} / 2018$ which gives a share of inheritance through a will of obligatory for children non-muslim. In addition to non-Muslim children, the share of inheritance is also given to non-Muslim wives through a mandatory will in the cassation decision Number 16 K/: $\mathrm{g} / 2010$ dated April 16, 2010.

From the description above, it can be found that the large portion of the inheritance received by non-Muslim warists is based on the statute of obligation. This shows that in determining the size of the inheritance for non-Muslim heirs, it is very dependent on the judge's consideration. The provisions that apply with certainty are only the part of the mandatory will not exceeding $1 / 3$ of the inheritance. In this case, the distribution of the Wanisan share to non-Muslim heirs through a mandatory will still leaves discrimination against non-Muslim heirs, because there is no certainty regarding the size of the inheritance received and the position is not equal to that of Muslim heirs. Such conditions will not occur in the event that the judges consider The law of hadith concerning the prohibition of inheritance of different religions in examining and adjudicating inheritance cases involving non-Muslim inheritance 
experts. As long as there are no elements of hostility and crime between heirs and heirs, then there is no obstacle to mutual inheritance between Muslims and nonMuslims.

\section{CONCLUSION}

It is the consensus of scholars that religious differences (Muslims and nonMuslims) are one of the hindering factors in being able to inherit. With regard to religious differences, what was agreed upon by these scholars was that non-Muslim heirs, either because they were not Muslim from the start or because they came out of Islam, could not inherit Muslim heirs.

The mandatory will given by the Supreme Court is for non-Muslim siblings. In fact, the mandatory will in $\mathrm{KH} 1$ is analogous to adopted children and adoptive parents, religious differences are still one of the barriers to inheriting each other. by seeking a positive step without limiting the understanding of inheritance law so far. In the law of inheritance, it has been explained that a person who leaves Islam is not entitled to inherit from his Muslim relative. It is the same with a Muslim who cannot inherit from a non-Muslim.

\section{REFERENCES}

[1] Abdul Ghofur Anshori, Filsafat Hukum Kewarisan Islam: Konsep kKewarisan Bilateral Hazairin. Yogyakarta: UII Press, 2005.

[2] N. Musyafa'ah, "Filsafat Kewarisan dalam Hukum Islam," Al-Qanun: Jurnal Pemikiran dan Pembaharuan Hukum Islam, vol. 20, no. 1, 2018, doi: 10.15642/alqanun.2017.20.1.56-76.

[3] Edy Sanjaya, Rangkuman Materi Perkuliahan Hukum Waris. Semarang: FH. UNTAG, 2018.

[4] M. Arif Rinaldy, "Pemberian Wasiat Wajibah Terhadap Ahli Waris Beda Agama," De Lega Lata, vol. 2, no. 2, 2017.

[5] B. Hariyanto, "Tinjauan Yuridis Terhadap Pembagian Harta Waris Beda Agama Menurut Kitab Undang Undang Hukum Perdata (Kuh Perdata) Dan Kompilasi Hukum Islam (KHI)," IUS, vol. 8, no. 2, 2021, doi: 10.51747/ius.v8i2.688.

[6] A. Z. Hakespelani, "Hukum Perkawinan Beda Agama Terhadap Hak Perwalian Dan Kewarisan Anak," ADLIYA: Jurnal Hukum dan Kemanusiaan, no. Vol 9, No 1 (2015): ADLIYA : Jurnal Hukum dan Kemanusiaan, 2015.

[7] S. S. Y. Yanti, Mulyadi, and Yunanto, "Pembagian harta warisan terhadap ahli waris beda agama serta akibat hukumnya," Diponegoro law journal, vol. 5, no. 3, 2016.

[8] Mardani, Hukum Kewarisan Islam di Indonesia. Jakarta: Raja Grafindo Persada, 2015.

[9] T. Taufiqurrahman, "Kompilasi Hukum Islam: Suatu Formalisasi Syariat Islam di Indonesia," AL-IHKAM: Jurnal Hukum \& Pranata Sosial, vol. 1, no. 2, 2019, doi: 10.19105/al-lhkam.v1i2.2559.

[10] F. Hedi, A. G. Anshori, and H. Harun, "Legal Policy of Interfaith Marriage in Indonesia," Hasanuddin Law Review, vol. 3, no. 3, 2017, doi: 10.20956/halrev.v3i3.1297.

[11] S. Dahwal, "Hubungan Hukum Keluarga Dan Hukum Kewarisan Islam Dalam 
Masyarakat Modern Indonesia," Supremasi Hukum: Jurnal Penelitian Hukum, vol. 28, no. 1, 2019, doi: 10.33369/jsh.28.1.17-32.

[12] Fathurrrahman, Ilmu Waris. Bandung: Al-Ma'arif, 1975.

[13] Achmad Jarchosi, "Pelaksanaan Wasiat Wajibah," ADHKI: Journal of Islamic Family Law, vol. 2, no. 1, 2020, doi: 10.37876/adhki.v2i1.34.

[14] S. Husien and A. Khisni, "Hukum Waris Islam Di Indonesia (Studi Perkembangan Hukum Kewarisan Dalam Kompilasi Hukum Islam Dan Praktek Di Pengadilan Agama )," Jurnal Akta, vol. 5, no. 1, 2017, doi: 10.30659/akta.v5i1.2533. 